\title{
EXPLORING THE DYNAMICS OF SECESSIONIST SENTIMENTS IN ALASKA
}

\author{
Ario Bimo Utomo \\ Universitas Pembangunan Nasional "Veteran" Jawa Timur \\ e-mail: ariobimo.utomo@gmail.com
}

\begin{abstract}
This article explores the dynamics of secession in Alaska, a state within the United States of America. Alaska has been an integral part of modern American history when it was admitted as the second-youngest state after Hawaii in 1959. The territory was initially purchased by the United States from the Russian Empire in 1867 due to the latter's concern of the expected British invasion. Putting the colonial narratives aside, Alaska is also a home of the Indigenous Alaskans with distinct identities compared to the European settlers. Viewing this contested history, combined with controversies leading to the inclusion of Alaska to the United States proper, one might assume that Alaskans might possess a higher sentiment of self-determination compared to the rest of Americans. However, despite those backgrounds, secessionism is not a salient issue in Alaska. Therefore, the author explores why the support for Alaskan secessionism is relatively unheard of despite the disputed history of the state. Using Hechter's model of secession (1992), the author proposes that Alaska has been experiencing a relatively low level of secessionist sentiment due to (1) a low level of group identification among the Alaskans themselves, (2) a weak regional party, (3) a high level of economic dependency on the host state, and (3) an unfavorable institutional environment for secessionist sentiments to be advanced. The research concludes by suggesting that secessionism in Alaska is not a favorable choice due to every limitation it faces.
\end{abstract}

Article information

Received: 4 January, 2019

Revised:18 January, 2019

Accepted: 1 February, 2019

Keywords: AIP; Alaska; history; postcolonialism; secession

DOI $\quad$ : https://doi.org/10.22146/rubikon.v6i1.61487

Available at https://jurnal.ugm.ac.id/rubikon/article/view/61487

This work is licensed under a Creative Commons Attribution-ShareAlike 4.0 International License

\section{INTRODUCTION}

The global landscape is ever-changing. If we look into every political map since the dawn of history, we can examine that borders are dynamic and never static. This case also occurs to states which we regard as "ancient" such as Greece, Ethiopia, and China. In the past, borders are defined by conquests, dynastic marriages, as well as commercial exchanges (Mayall, 2016).

Since the dawn of the Westphalian system, the world has witnessed the era where 
nations have their own border and their own political sovereignty to take care of their own affairs without any foreign interventions. Not only that, but this Westphalian system has also designed in such a way to make those particular states governed by a government from a nation which represents the constituents, hence the concept of the nationstate. The concept of nation-states, therefore, brings us to the debate on nationalism. Primordialists argue that nations are given. This means that nationalism is a natural occurrence, and the border of current nationstates are consistent since the beginning of time with only little changes. On the other hand, there is also the camp of modernists, who believe that nations are recently invented and, thus, politically constructed (Anderson, 1991; Gellner, 1983).

The rise of nationalism in the $19^{\text {th }}$ century has brought a new trend toward the Westphalian nation-state system. States were not regarded as the private possessions of the dynasty anymore, rather, sovereignty had to be transferred to the people. As the result, states cannot survive without the consent of the people as the nation (Mayall, 2016). The aforementioned background brings us to a new problem when states try to exercise its powerupon its population to create a single identity as a nation. However, this not to say that such attempts are met with no resistance. In some states, particularly the heterogeneous ones, the problem with divided loyalty is not a rare occurrence. In China, for instance, some Uyghur populations of the Xinjiang Autonomous Region are reluctantly accepting their status as the Chinese citizens and instead see themselves as the "East Turkestan" people, citing their proximity with the Turkic nations (Lee, 2006). In post-colonial states, the problem can also be more troubling. Most post-colonial states' identity is built upon the shared history of being colonized, differing from the primordial assumption that their states were naturally given and had already been established since the beginning of time.

There is a number of ways in fulfilling such national self-determination, one of which is through secession. The term itself originates from the Latin words " $s e$ " meaning "apart" and "cedere" meaning "to go" (Pavkovic \& Radan, 2014). As a political move, secession has an aim to create a new state on a territory which advocates it. Technically, defining secession is a more complex matter. Pavkovic and Radan (2014) offertwo contrasting views in defining secession. One definition stipulated by Crawford (2006) saying that secession is "the creation of a state by the use of threat of force without the consent of the former sovereign" (p. 375). On the other hand, a more moderate definition by Radan (2008) offers that secession does not necessarily need a use of force, as it only needs to be understood as "the creation of a new state upon territory previously forming part of, or being a colonial entity of, an existing state" (p. 18). The latter definition suggests that secession can occur even with the consent of the host state, leading to the consequence that secession is not a rare phenomenon.

This article is going to discuss a case of secessionism in Alaska, a state of the United States of America. In the following sections, the author shall begin with clarifying the theoretical background used in this article. Next, this article will discuss the brief background of Alaska before diving into the case through each point laid by the theoretical background to explore the dynamics of secessionism in Alaska. 
Secessionis a force of change which can alter the course of international relations. It brings new states, autonomous regions, and even insurgent groups to existence. However, the scholarship on secessionism has just emerged recently with a demand to understand the logic behind such activity. Wood (1981), for instance, pinpoints how the development ofan explanatory framework in explaining secession had been lacking behind despite it being an important political phenomenon.

In the 1960s and early 1970s, political scientists became so engrossed in the study of transnational politics and the evolution of supranational 'communities' that they were unprepared for the explosive proliferation of movements aimed in the opposite direction. Thus, in the early 1980s, despite the achievements of a few comparative studies, a general explanation remains to be given of how, when, and why 'things fall apart' in increasing numbers of contemporary states (p. 107).

Today, there have been different theoretical frameworks in observing secessionism. However, secession is not a condition which can be analyzed through a one-size-fits-all toolkit. Researchers have attempted to analyze this phenomenon through several lenses. Hoeffler (2006) sees secession through the economic lens, for instance. For them, economic preconditions can bring a causal explanation why do groups decide to secede from their host state. On the other hand, scholars like Radan (2012) and Kohen (2006) observe secession as a product of the international law dynamics. For the sake of simplicity, the author chooses a framework which can integrate several important aspects of secession. Therefore, this research is based on the work of Hechter
(1992) in his article The Dynamics of Secession (1992). His model is useful in forecasting under what conditions do secession tendencies occur.

Hechter begins with arguing that the decision to secede is a matter of rational choice. He offers two factors which can lead to the act of secession. First, there should be a collective decision from the population to secede. Second, there needs to be a leader which can translate such demands into a political move to secede. In order to be rational, Hechter adds, the cost of seceding from the host state should be negative compared to the benefits.

In Hechter's conception, the dynamics of secession can be determined through four aspects.

1. The establishment of collective agreement about what constitutes a "region" as well as their common interests.

2. The establishment of collective actions, such as the willingness of the regional population to form social movements and political parties in order to advance their common interest.

3. The social bases. This aspect is to determine whether or not the region is better off with the host state. Economic dependency is a good, but not limited to, variable to determine this. Regions with a high level of dependency are more inclined to stay within the union.

4. The decision of the ruler. Secession can only occur when the rulers of the host nations agree to relinquish the sovereignty of their respective regions. This means that one should look into the 
perception of the host state regarding any possibility of secession.

To answer those points, at least there are three important data need to be collected. First is the data on the region's population in regard to the issue of secession. Second, we also need to examine the socio-economic indicators of the studied region. Last but not least, Hechter also suggests finding data relevant to factors leading to decision makers' choice with respect to secession. While the first and the third kind of data are not always available in all cases, the second data is usually abundant.

\section{DISCUSSION}

The state of Alaska is unique in many ways. Alaska is the $49^{\text {th }}$ state of the United States, making it the second last to be admitted in the union. It ranks first as the largest state in terms of area, with 665,384 miles square of land mass. Despite being the largest state in terms of area, Alaska is also the most sparsely-populated American state with only 738,068 people inhabiting it (“Alaska Population 2018," 2018). Geographically, Alaska is peculiar as it is not contiguous to the rest of the United States proper, a trait it shares with the state of Hawaii.

The history of Alaska is also filled with complexity. Long before the colonialization by the Russian Empire in the 1700's, Alaska had already been a home to the indigenous Alaskan such as the Inuits and Eskimos with their own cultural characteristics. Once the Russian came, the region had then turned into a center for the fur trade, where the indigenous Alaskans were reportedly being exploited as labor workers (Essary, 2008). However, in 1867, the Russian Empire sold
Alaska to the United States which led us to two possible explanations: the first is the inability to control the budget needed to manage Alaska as their region, another one is a possibility that the Russians did not want risk Alaska to fall into the hands of Britain. In 1868, the United States finalized their purchase of Alaska by paying Russia 7,2 million dollars.

As the region was incorporated in the late nineteenth century, the twilight of the American expansion, its process of integration lacks behind other regions which had originally been incorporated earlier. Its natural features, as well as its historical backgrounds, have made Alaska's image to be known as the exotic territory located at the far-north, underdeveloped, wild, and distanced from the hustle of the mainland United States. Such imagery is reinforced through its nickname as "The Last Frontier" of America (Haycox, 2002).

Alaska's status in the United States had experienced several changes. From 1867 to 1884, Alaska was regarded as the military district of the United States under direct supervision from the federal government. In 1884, the First Organic Act granted Alaska with civil officials which were appointed by the federal government. In 1912, the Second Organic Act had enhanced the status of Alaska even further by turning it into an organized territory with its own legislature rights to pass laws. However, Alaskans still saw minimum benefit from those agreements. A Statehood Bill had then offered to the federal government in the same year with the ratification of the Second Organic Act. However, Alaska's quest for statehood was not realized until 1958 through an election whose agenda is to elevate the status of 
Alaska from territory to state. The election went in favor of the statehood, thus establishing the status of Alaska as the $49^{\text {th }}$ state. However, that did not signify the end of the debate, as some groups regard that the election was flawed. Joe Vogler, a prominent Alaskan secessionist, argue that Alaska should have been given an option to secede from the United States. His advocacy led to the creation of the Alaskan Independence Party (AIP) in 1973. The creation of AIP marked the beginning of contemporary debates on secessionism in Alaska.

With those backgrounds, Alaska would be an interesting case study in examining how the dynamics of secessionism occur within a post-colonial region with such contested identity. There might be some questions regarding the problem with its selfdetermination tendencies, especially whether contemporary Alaska serves as a ripe ground for secessionism to emerge. Secessionism itself is not a new issue in Alaska, as there has been reemergence regarding this issue in the last decade. The following sections of this article will analyze the case by dissecting the points offered by Hechter.

\section{Group Identification}

The first topic through which one should begin is seeing the group identification within the region. This relates to how the constituents of the region perceive themselves, which is an important departing point if we are to use the modernist's assumption on nationalism which sees national identity as constructed or imagined. Secession begins when a group of people, or "nations", start believing that they belong to the different community than those which rule their host nation. In order to know that, we should understand what constitutes the distinctively "Alaskan identity".

The Alaskan demographic today is quite plural. As per 2017, the United States Census Bureau reported that five major racial groups in Alaska are whites $(65.8 \%)$, native Alaskans (15.3\%), Hispanics (7.1\%), Asians (6.5\%), and blacks $(3.7 \%)$. Superficially, it seems that the "Alaskan identity" is not a strong driver here, as the native Alaskans comprise less than one-fifth of the total population. Moreover, "native Alaskan" is not a monolithic term since it comprises different ethnic groups like the Inuits, Eskimos, and Aleuts with their own cultural andlinguistic differences. Even if those groups belonged to one single identity, there has been no observable instance of an ethnic-motivated secessionist movement in Alaska. This initial analysis disproves the argument that Alaskan secession is based on primordial sentiments.

Essary (2008) finds that there are generally two reasons why the native Alaskan did not push for independence. The first one is a problem with Alaska's postcolonial history. During its history, Alaska had been exposed to two foreign powers: Russia and the United States. The long-standing existence of foreign settlers in Alaska had made native Alaskans not organized as one entity.This problem also can be found from the legal perspective. In 1867, when the transfer of jurisdiction from Russia to the United States was finished, The Treaty of Cession regarded the native Alaskans as the "uncivilized tribes". However, in 1871, Washington decided to end the use of treaties as the basis of the relation between the federal government and the native tribes (Langdon, 2016). This, to some extent, had made the process of self-identification lagged behind. 
Second, it turns out that the mobilization of the native Alaskans is more motivated by civic rather than ethnic reason. When faced with issues such as inequality or underdevelopment, native Alaskans will resort to arguments about civil rights rather than using a collective Alaskan identity. Therefore, it can be said that the basic group identification among the titular native Alaskan has been extremely low.

\section{Collective Actions}

After understanding how the group identification in Alaska occurs, the next step is to understand whether such identifications lead to further collective actions. The mere existence of a group identification does not automatically turn into a demand to withdraw from a union. From the previous section, we observe that ethnic argument does not fit into the case of Alaska. This aligns with Hechter's argument that primordial logic brings little explanation on how secessionism varies in empirical terms.

In Alaska, secessionism is led by the AIP as the sole party which advocates secession. AIP emerged as a social movement called the Alaskans for Independence (AI), founded by Joe Vogler in 1973. He founded this movement under the basis that the United States government violated the 1958 Statehood Bill by not granting rights to vote to the Alaskan people. He also objected the federal control upon the resources in Alaska. Therefore, once again, Vogler's intention was to create a civic movement rather than using a "native-first" rhetoric to advocate the interests of the Alaskans.

In 1984, AI evolved into AIP. According to its official website, the AIP claims to be the only party that is "entirely composed of
Alaskans, staffed by Alaskans, and financed by Alaskans...not affiliated with any political party on a national level". AIP sees that the 1958 Statehood Election was flawed. According to them, Alaskans were denied a right to vote in the statehood. Therefore, they actively advocate another vote on secession withfour alternative options which consist of:

1. Remaining a territory, a status possessed by Alaska prior to the 1958 Statehood Election.

2. Becoming a separate and independent nation.

3. Accept Commonwealth status, thus putting Alaska on the same level with Puerto Rico and the Northern Mariana Islands.

4. Become a state or maintaining the status quo.

Accordingly, AIP does not necessarily push for independence. Rather, they play within the corridor of democracy to offer a voting agenda for the Alaskans so they can decide their fate for themselves. AIP views that 1958 was "corrupt" and the residence "was not given proper choices". AIP's main concern is that the federal government know little about what Alaska really needs. The assumption is based upon the concern that Alaska had long been experiencing colonialism, leading to exploitation of important resources. Through their website, AIP claims that their movement is entirely civic as opposed to ethnic, saying that the support "comes from a coalition of native Alaskans and white and black working people who primarily reside in rural Alaska" (Collet, 2006). 
Despite the Alaska-first agendas, AIP remains a fringe party in Alaskan politics. Alaska has long been known as a "red" state where the majority of the population support the Republican Party (Leip, 2016). As per 2018, AIP's registered voters are recorded to be 17,118 or equivalent to $3.16 \%$ of total voters in Alaska ("Numbers of Registered Voters by Party within Precinct Date 07/03/2018," 2018).

\section{Social Bases}

A region is more likely to secede when the constituents think that they are able to sustain themselves in the absence of the federal government. This point signifies that the less a certain region is dependent on others - particularly the host state - the more favorable is the condition of secession for the region. is the next case which we are going to analyze. In former sections, we have seen that the Alaskan economic accounts only a little among all the American states. To analyze this section, we will need to observe the economic performance of the state.

The Alaskan economy is highly dependent on the mining sector, particularly oil. Despite that, Alaska's contribution toward the federal Gross Domestic Product (GDP) is relatively low compared to other states. In 2017, Alaska contributed only 52.79 billion US dollars, 46 ${ }^{\text {th }}$ among all American states ("GDP of the United States in 2017, by state," 2018).

The Alaskan economy is extremely dependent on the primary sector. According to the Alaska Economic Report (2017), comparing trends from the first and second quarters from 2013-2017, non-manufactured commodities such as raw fish, crude oil, and metal ores account most for the Alaskan export. On the other hand, manufactured commodities "make up 87 percent of imports to the state" (p. 3).

Other than that, it is apparent that Alaska is highly dependent on federal income. From the tables below, which are retrieved from Goldsmith (2010), federal sectors account for approximately $35.3 \%$ of total employment in Alaska. On the other hand, the central government is also accountable for $39.8 \%$ of the total residential personal income. This indicates that there is a high level of dependency toward the central government in Alaska. Therefore, according to Hechter's model, this kind of condition does not provide a fertile soil for secessionists to maximize their agenda. Petroleum sectors, which are regarded as the main internal economic driver for Alaska, only comes second with $31.2 \%$ for total employment and $29.8 \%$ for resident personal income. 


\begin{tabular}{|c|c|c|c|c|}
\hline & \multicolumn{2}{|c|}{ Employment } & \multicolumn{2}{|c|}{$\begin{array}{l}\text { Resident Personal } \\
\text { Income }\end{array}$} \\
\hline & Thousand & Share & Billion \$ & Share \\
\hline TOTAL & 377.3 & & $\$ 24.94$ & \\
\hline FEDERAL & 133.3 & $35.3 \%$ & $\$ 9.93$ & $39.8 \%$ \\
\hline Non Defense & 73.7 & $19.5 \%$ & $\$ 6.19$ & $24.8 \%$ \\
\hline National Defense & 59.6 & $15.8 \%$ & $\$ 3.75$ & $15.0 \%$ \\
\hline PETROLEUM & 117.6 & $31.2 \%$ & $\$ 7.44$ & $29.8 \%$ \\
\hline Production & 51.48 & $13.6 \%$ & $\$ 3.45$ & $13.8 \%$ \\
\hline State/Local Revenues & 52.9 & $14.0 \%$ & $\$ 2.71$ & $10.9 \%$ \\
\hline Permanent Fund \& CBR & 13.3 & $3.5 \%$ & $\$ 1.29$ & $5.2 \%$ \\
\hline TRADITIONAL RESOURCES & 49.3 & $13.1 \%$ & $\$ 2.41$ & $9.7 \%$ \\
\hline Seafood & 38.7 & $10.3 \%$ & $\$ 1.77$ & $7.1 \%$ \\
\hline Mining & 8.5 & $2.3 \%$ & $\$ .54$ & $2.2 \%$ \\
\hline Timber & 1.9 & $.5 \%$ & $\$ .94$ & $.4 \%$ \\
\hline Agriculture & 0.15 & $0 \%$ & $\$ 0$ & $0 \%$ \\
\hline NEW RESOURCES & 50.0 & $13.3 \%$ & $\$ 2.35$ & $9.4 \%$ \\
\hline Tourism & 41.5 & $11.0 \%$ & $\$ 1.83$ & $7.3 \%$ \\
\hline Air Cargo & 7.8 & $2.1 \%$ & $\$ .48$ & $1.9 \%$ \\
\hline $\begin{array}{l}\text { Other Manufacturing and } \\
\text { Services }\end{array}$ & 0.66 & $.2 \%$ & $\$ .04$ & $.2 \%$ \\
\hline PERSONAL ASSETS & 27.0 & $7.2 \%$ & $\$ 2.80$ & $11.2 \%$ \\
\hline Retirees & 20.8 & $5.5 \%$ & $\$ 2.18$ & $8.7 \%$ \\
\hline Non-Earned Income & 6.2 & $1.7 \%$ & $\$ .62$ & $2.5 \%$ \\
\hline
\end{tabular}

\begin{tabular}{|c|c|}
\hline & Billion \$ \\
\hline FEDERAL SPENDING & \\
\hline Non Defense & $\$ 4.07$ \\
\hline National Defense & $\$ 2.13$ \\
\hline PETROLEUM & \\
\hline Production & $\$ 1.57$ \\
\hline State/Local Revenues & $\$ 1.29$ \\
\hline Permanent Fund \& CBR & $\$ .98$ \\
\hline & \\
\hline TRADITIONAL RESOURCES & \\
\hline Seafood & $\$ .73$ \\
\hline Mining & $\$ .26$ \\
\hline Timber & $\$ .05$ \\
\hline Agriculture & $\$ 0$ \\
\hline & \\
\hline NEW RESOURCES & \\
\hline Tourism & $\$ .83$ \\
\hline Air Cargo & $\$ .23$ \\
\hline Other Manufacturing and & \\
\hline Services & $\$ .02$ \\
\hline PERSONAL ASSETS & \\
\hline Retirees & $\$ 1.71$ \\
\hline Non Earned Income & $\$ .48$ \\
\hline Core Income for EcOnOmic & $1 v e r s$ \\
\hline
\end{tabular}

Table 2. Core Income for Economic Drivers (2005-2007)

Those numbers tell us that the collective actions conducted by AIP fall short due to high dependency to the central government. This, to some extent, can explain why does the support for AIP, or secessionism, remains low in Alaska. However, this claim still needs to be tested in further researches. This preliminary observation can conclude that the point of the social base for the Alaskans remains unfavorable for secession.

On the other hand, other secessionist states of the United States such as California or Texas excel in this aspect. The former accounts for 2,746.9 billion US dollars, the primary contributor of the American GDP in 
2017; the latter comes second, contributing 1,696.2 billion US dollars toward the United States' GDP ("GDP of the United States in 2017, by state," 2018). This shows how Alaska is currently lacking so far behind, thus making it harder for them to unilaterally demand secession.

\section{The Decision of the Ruler}

Lastly, we need to examine how is the attitude of the host state toward general secessionist sentiments within its borders. Whether or not a host state is willing to accommodate secession sentiments is a matter of importance in this case. The results may vary among different countries, Hechter notes that there are three mechanisms to cope with secessionist demands that can be done by the host state.

First, the state can offer incentives to the secessionist groups. This is done in the expectation that the group would eventually abandon their desire to secede. This can be done through development projects or resources which can enhance the quality of the region without necessarily losing the sovereignty over it. Second, states can also offer constitutional reforms. This second solution is a more costly one as it involves the host state to allocate more resources in order to curb secessionist sentiments within its borders. This can be done through granting more autonomy to the regions which seek to secede. This instance can be found in cases like Quebec (Canada) or Aceh (Indonesia) which have been enjoying a higher degree of autonomy following demands to secede. Lastly, states can also exercise repression toward secessionist groups. Even though it is not the most favorable choice under democracy, it can be used as the last resort when the two initial moves failed to end secessionism. However, Hechter argues that this move is the costliest one because of its relations to several factors, namely geography, military capacity of the host state, and the third-party involvement in the repression.

The constitution of the United States does not specifically mention the right to secede. In the Articles of the Confederation, however, it does include a subtle reference that the Union is "perpetual". After the Civil War, the Supreme Court of the United States has declared that such "perpetual union" is to be refined to form "a more perfect union" (Stampp, 1978). The tragic history of the Civil War has made it theoretically impossible for states to withdraw from the United States. Rob Vischer also adds that "there are certain background premises that make our system of government possible, and one of them is the union is permanent" (in DeRusha, 2012). This last point shows again that Alaskan secessionism would possibly meet impending conditions. This time is due to the host state skepticism in approaching any possibility of secession.

\section{CONCLUSION}

This research is intended as a preliminary observation regarding the dynamics of secessionism in one of the states of the United States, Alaska. The author chooses Alaska as a litmus test as it is a region which displays a degree of secessionist sentiments.

Using Hechter's model on secession dynamics, the author pinpoints several important points which can explore how the dynamics of secession is going so far in Alaska. From the discussions, we can 
conclude that among all the four points offered by Hechter, none signals positively toward the dynamics of secession in Alaska. First, despite the existence of the native Alaskans, it does not contribute positively toward group identification because of the disorganized nature of the population. Second, we can also see that while collective actions have been translated into the creation of AIP, the party remains insignificant to push the demand of secession due to the lack of popular support among the Alaskans themselves. Third, through analyzing the social bases of the Alaskan people, we can eventually understand that Alaska is highly dependent on the host state, thus making independence less favorable. Lastly, through observing the attitude of Washington toward secession, we can see that secession has never been a viable option in the United States as the constitution regards secession as an illegitimate action.

The author realizes that there are many limitations to this study. However, through the discussed case study, we would be able to observe secession through a more systematic lens. This is not to say that secession will never happen in the studied region, but it can serve as a forecast on how things will be going under different empirical examples. Finally, the author hopes that this study can contribute positively toward the development of studies on secession.

\section{REFERENCES}

Alaska Population 2018. (2018). Retrieved from http://worldpopulationreview.com/states/ alaska-population/

Anderson, B. (1991). Imagined Communities. Nationalism. https://doi.org/10.1080/13825570420002 94701

Collet, C. (2006). Alaska Independence Party Introduction. Retrieved from http://www.akip.org/introduction.html

Crawford, J. (2006). The Creation of States in International Law. Oxford University Press.

DeRusha, J. (2012). Good Question: Can a State Secede from the Union. Retrieved from

https://minnesota.cbslocal.com/2012/11/ 14/good-question-can-a-state-secedefrom-the-union/

Essary, E. (2008). Latent Destinies: Separatism and the State in Hawaii, Alaska, and Puerto Rico. Duke University.

GDP of the United States in 2017, by state. (2018). Retrieved from https://www.statista.com/statistics/24802 3/us-gross-domestic-product-gdp-bystate/

Gellner, E. (1983). Nations and Nationalism. New Perspectives on the Past. https://doi.org/10.1111/1469-8219.00146

Hoeffler, A. (2006). The Political Economy of Secession. Retrieved from https://ora.ox.ac.uk/objects/uuid:702908 ce-0810-4810-ad1f-28c2cbe38921

Kohen, M. G., \& Kohen, M. G. (Eds.). (2006). Secession: International Law Perspectives. Cambridge University Press.

Haycox, S. (2002). Frigid Embrace: Politics, Economics, and Environment in Alaska. Corvallis: Oregon State University Press.

Langdon, S. (2016). Determination of Alaska Native Status Under the Marine 
Mammal Protection Act. Juneau.

Retrieved from

http://www.sealaskaheritage.org/sites/de

fault/files/MMPAFinalReport.pdf

Lee, J. (2006). The Islamic Republic of Eastern Turkestan and the Formation of Modern Uyghur Identity in Xinjiang. Kansas State University. Retrieved from http://www.dtic.mil/dtic/tr/fulltext/u2/a4 55923.pdf

Leip, D. (2016). United States Presidential Election Results. Retrieved from https://uselectionatlas.org/RESULTS/

Mayall, J. (2016). Secession and International Order. In The Ashgate Research Companion to Secession, 35-46. Surrey: Ashgate Publishing Limited.

Numbers of Registered Voters by Party within Precinct Date 07/03/2018. (2018). Retrieved from http://www.elections.alaska.gov/statistic s/2018/JUL/VOTERS BY PARTY AND PRECINCT.htm\#STATEWIDE

Pavkovic, A., \& Radan, P. (2014). The Ashgate Research Companion to Secession. Political Studies Review.

Stampp, K. (1978). The Concept of a Perpetual Union. Journal of American History, 65 (1), 5-33.

Wood, J. R. (1981). Secession: A Comparative Analytical Framework. Canadian Journal of Political Science/Revue Canadienne de Science Politique, 14(1), 107-134. 